\title{
Tumbling into a Crisis: Use of Corporate Apologia after USA Gymnastics Falls off the Balance Beam
}

\author{
Terry L. Rentner \\ Bowling Green State University \\ Bowling Green, OH USA \\ Cory Young \\ Ithaca College \\ Ithaca, NY USA
}

\begin{abstract}
In an open letter to U.S. gymnasts on Nov. 5, 2018, United States Olympic Committee (USOC) CEO Sarah Hirshland told its more than 150,000 members "You deserve better" as it launched the Nuclear Clause that would revoke USA Gymnastics (USAG) as a governing body for the sport at the Olympic level [1]. This announcement comes in the wake of USAG's ongoing crisis that includes a failure to protect athletes from team doctor Larry Nassar, imprisoned for sexually abusing more than 350 female gymnasts; investigations tied to Michigan State University; and the turnover of several USAG CEO's in just two years. The research question addressed in this study asks how gymnastics can recover from a crisis that was decades in the making and two years in the public spotlight. Benoit's (1997) Image Repair theory as well as Hearit and Courtright's (2004) social constructionist approach and apologia discourse inform our critical analysis on how and why USAG has tumbled.
\end{abstract}

Keywords - Corporate Apologia Theory, Image Repair Theory, USA Gymnastics, United States Olympic Committee

SUGGESTED CITATION: Rentner, T. L., \& Young, C. (2019). Tumbling into a crisis: U.S. olympic committee's use of corporate apologia after USA gymnastics falls off the balance beam. Proceedings of the International Crisis and Risk Communication Conference, Volume 2, (pp. 27-30). Orlando, Fl: Nicholson School of Communication and Media. https://doi.org/10.30658/icrcc.2019.8

\section{INTRODUCTION}

USA Gymnastics (USAG) fall of the balance beam was an unmistakably thud. The dismount began in 1992 when a 12year-old filed a lawsuit against Larry Nassar, then a medical student at Michigan State University (MSU). In 1994, MSU's Title IX coordinator investigated allegations of misconduct by Nassar but found no evidence. In January of 2017, 18 women filed a lawsuit in federal court against Nassar, followed by 23 more female gymnasts in June 2017. How had USAG and MSU missed or disregarded opportunities to investigate claims of sexual misconduct by Nassar, who was hired by MSU as the gymnastics team physician and assistant professor and USAG as its national medical coordinator? It took a 2016 investigative piece by the Indianapolis Star before USAG and MSU publicly addressed sexual abuse allegations both allegedly knew about for years. By then, each organization was in reactive mode with their communication efforts and only recently in early 2019 were both able to establish proactive efforts to address this crisis.

This case study first will explore the specific image repair discourses used by the USAG and MSU and why attempts failed. We then describe how the USOG's and MSU's use of corporate apologia may be effective in fostering a safer environment for its athletes. Finally, we offer a best practices model of crisis communication strategies within a sport organization and for the media and public. 


\section{BACKGROUND}

The crisis began long before Michigan State USAG team doctor Larry Nassar was relieved of his duties in 2015 and fired in 2016. Multiple victims had complained to MSU coaches, therapists, and administrations that they had been touched inappropriately but were told not to worry, that this was part of "actual medical treatment" [2, para.1]. Multiple lawsuits filed against Nassar since 1992 did not raise any flags until 2015 when USAG then president and CEO Steve Penny notified law enforcement of athlete concerns about Nassar. The 2016 investigative piece in the IndyStar brought public attention to the high number of gymnasts (368) claiming sexual abuse and 24 years of allegations of sexual abuse inside USAG. The USAG Board of Directors quickly announced a policy review panel and hired a public relations firm. In early 2017, USAG released a timeline of actions it took against Nassar, but after more than two years of revolving CEOs and attempts at damage control, the US Olympic Committee (USOC) had enough and in December 2018 invoked the "nuclear clause" essentially revoking the USAG as the governing body of gymnastics. The USAG then filed for bankruptcy and USOG offered a letter of apology to its members. In the open letter USOG CEO Sarah Hirshland told its members that it is difficult to belong to an organization that "continues to struggle to change its culture, to rebuild its leadership and to effectively serve its membership" as attempts began to resolve the crisis [3, para. 7].

At the same time, MSU was facing its own series of issues involving Nassar. In his sentencing hearing, Judge Rosemarie Aquilina sentenced Nassar to a minimum of 40 years and a maximum of 175 years in a Michigan state prison saying, "I've just signed your death warrant" [4, para. 7]. MSU President Lou Anna Simon resigned that night. Further problems for MSU included a vote of "no confidence" in the hiring of former Michigan Governor John Engler as interim president, Engler asking a Nassar victim to settle her case, and Nassar's supervisor at MSU arrested and charged with criminal sexual conduct. Shortly thereafter, the NCAA investigated MSU's handling of the case that resulted in a $\$ 500$ million settlement with 332 of Nassar's victims.

Both USAG and MSU have recently attempted to repair their images. These include the decertification of the USAG by the USOG, the $\$ 500$ million settlement to the survivor Fund, and the establishment of the Healing Fund.

\section{PROCEDURES}

Many communication scholars have used image repair theory to analyze crisis events and the ways organizations and individuals respond. Benoit [5] offers five broad strategies for restoring one's image:

1) Denial—organization did not perform the act, or was performed by another

2) Evade responsibility — organization claims what happened was a mishap, accident, or due to a lack of information

3) Reduce offensiveness - organization attempts to repair its image by bolstering, minimizing, differentiating, transcending, attacking or compensating

4) Corrective action - organization reveals a plan or strategy to solve the problem or prevent it

5) Mortification —organization or individual apologizes for the act.

Benoit also offers suggestions for how organizations and/or individuals should use these strategies effectively. Before a crisis occurs, prepare a crisis contingency plan. Gather as much information before creating a response. Identify key stakeholders to target messages. Redefine the attack and refocus attention to other issues. Tell the truth - avoid false claims, admit fault, shift blame appropriately, strategy of defeasibility, report plans to correct/prevent problem. Use multiple strategies that will resolve the issue.

Hearit and Courtright's [6] social constructionist approach to crisis management posits that crises are "both created and resolved communicatively ... [and that] communication . . . actually constitutes the nature and experience of the crisis itself" (p. 202). Apologetic crises such as the USAG are rooted in the rhetoric of image repair and the discourse of defensea form of apologia. The authors provide the framework for "exposing the motives of rhetors and explicate their use of language" (p. 206) within USGA as it apologizes for "charges leveled by corporate actors (e.g., media or public interest groups) who contend that [the] organization is guilty of wrongdoing" (p. 211). This approach also includes two important elements. The first is a lack of an organization's terminological control. "Only when corporate actors, media, or government officials agree to label a problem as a 'crisis' do they respond as such" (p. 206). Even then, Hearit and Courtright caution that labeling an event as a crisis "conveys a sense of urgency; it suggests that the situation is out of control and implies that sacrifice may be needed in the quest for immediate attention and resolution" (p. 208). The second element is competing "proto-definitions [which] represent the conflicting interpretive schema offered by participants" (p. 206). These definitions of crises are strategic and persuasive.

By combining Image Repair Theory with the social constructionist approach to crises and the discourse of apologia to analyze how both the USGA and MSU tumbled, we begin to construct a more effective way for organizations to take responsibility for its actions.

\section{APPLICATION}

In examining this crisis, it is clear how Benoit's strategies emerged. First, the denial by MSU and USA gymnastics was 
evident as each organization received conflicting proto-definitions of the alleged charges against Nassar-as actual medical treatment [2], too many missed warning signs, and the evidence not sufficient to take the gymnasts seriously [7]. These proto-definitions set up the conditions for MSU, USAG, and the USOC to evade taking responsibility: "Neither the U.S.A. Gymnastics nor the U.S.O.C. have reached out to express sympathy or [sic] even offer support, [Raisman] said. Not even to ask: 'How did this happen?'... Why has the United States Olympic committee been silent?" [8, para. 19].

As the timeline of events unfold, USA Gymnastics, MSU, and the USOC begin to lose terminological control of the situation as others, such as the IndyStar, began telling the story. It was not until this moment that USAG and others begin corrective actions:

- February 16, 2017-USAG releases timeline of actions it took against Dr. Nassar

- February 18, 2017-Video statement from Paul Parilla, Chairman, USA Gymnastics chairman Board of Diversity reiterating the organization's efforts to protect athletes

- February 19, 2017—Press release issued related to former federal prosecutor Deborah J. Daniels' decision to review USAG

- December 2017-MSU opens $\$ 10$ million Healing Fund

- January 19,2018-MSU Board of Trustees requests investigation of university's handling of allegations against Nassar

- May 6, 2018-MSU and Nassar victims reach $\$ 500$ million settlement

- November 2018-USOC CEO Sarah Hirshland launched Nuclear Clause - revoked USGA as the governing body

- December 4, 2018- MSU redirects the remaining \$8.5 million in the Healing Assistance Fund toward its \$500 million settlement and is highly criticized

- January 17, 2019-MSU Interim President Engler resigns after remarks about victims

- January 2019-MSU re-establishes the Healing Assistance Fund

- February 15, 2019-SatishUdpa, Michigan State University's acting president, formally apologized to the survivors of Nassar at start of the Board of Trustees meeting

The last strategy identified by Benoit [5] is mortification in which several key actors in this crisis apologize for the act. USOC CEO Sarah Hirshland stated publicly, "You deserve better" [1, para. 8]. Parilla lamented, "USA Gymnastics is very sorry that anyone has been harmed during his or her gymnastic career, and we offer our deepest regrets to any athlete who suffered abuse or mistreatment" [9, para. 8]. Even Larry Nassar "quietly attempted an apology, saying, 'There are no words that can describe the depth and breadth for how sorry I am for what has occurred" [4, para. 1].

\section{CONCLUSION}

All sport governing bodies, institutions, and organizations could learn a lesson from the gymnastics sexual abuse crisis. Each must strategically align in policy, practice, and communication with its athletes and further communicate these to the media and public. Winchel's [10] presents three recommendations that weave together Benoit [5] and Hearit \& Courtright's [6] ideas. Her first recommendation is for USA Gymnastics to "Do more to apologize ... Words aren't enough," [10, para. 5] thus expanding upon the mortification strategy while "exposing the motives of rhetors and explicating their use of language" [6, p. 206]. Second, Winchel recommends USAG become digitally savvy by becoming more active on Twitter. This would allow the organization to take more terminological control over its story and directly connect with its target audiences-young women who are using social media to construct their experiences. Lastly, "a systemic problem requires a clean slate. Offering apologies and scrambling to fix a current firestorm won't help your organization's reputation, if the crisis to which you are reacting is widespread" [10, para. 20]. Wiping the slate clean, by developing a contingency plan before the next crisis occurs, will allow organizations like USAG and MSU to focus on reducing offensiveness, enacting corrective action, and minimizing competing proto-definitions, thus repairing the organization's image and restoring trust.

\section{Author Biography}

Terry L. Rentner (trentne@bgsu.edu) has a Ph.D. from Bowling Green State University (BGSU), OH. She is a Professor in the School of Media and Communication at BGSU.

Cory Young (young@ithaca.edu) has a Ph.D. from Bowling Green State University (BGSU), OH. She is an Associate Professor in the Department of Strategic Communication at Ithaca College, New York.

\section{REFERENCES}

[1] Brennan, C. (2018, November 5). US gymnasts 'deserve better,' USOC CEO Sarah Hirshland says. And she's right. USA Today. Retrieved from https://www.usatoday.com/story/sports/columnist/brennan/2018/11/05/usa-gymnastics-gets-whatdeserves-decision-usoc/1899112002/

[2] Kitchener, C. \& Wong, A. (2018, Sept. 12). The moral catastrophe at Michigan State University. The Atlantic. 
[3] Armour, N. \& Axon, R. (2018, November 5). USOC begins process of revoking USA Gymnastics' status as national governing body. USA Today Sports. Retrieved from https:/www.usatoday.com/story/sports/olympics/2018/11/05/usocbegins-process-revoking-usa-gymnastics-status/1896795002/

[4] Hobson, W. (2018, January 24). Larry Nassar, former USA Gymnastics doctor, sentenced to 40-175 years for sex crimes. The Washington Post. Retrieved from https:/www.washingtonpost.com/sports/olympics/larry-nassar-former-usagymnastics-doctor-due-to-be-sentenced-for-sex-crimes/2018/01/24/9acc22f8-0115-11e8-8acfad2991367d9d story.html?utm term=.00e846ee8573

[5] Benoit, W. L. (1997, Summer). Image repair discourse and crisis communication. Public Relations Review, 23,177 - 186. https://doi.org/10.1016/S0363-8111(97)90023-0

[6] Hearit, K. M. \& Courtright, J. L. (2004). A symbolic approach to crisis management: Sears' defense of its auto repair policies. In D. P. Millar and R. L. Heath (Eds.). Responding to crisis: A rhetorical approach to crisis communication. Mahwah, NJ: Lawrence Erlbaum Associates.

[7] North, A. (2018, January 25). Young women reported Larry Nassar for decades. No one took them seriously—until now. Vox. Retrieved from https:/www.vox.com/identities/2018/1/25/16928994/larry-nassar-mckayla-maroney-gymnastics-metoo

[8] Cacciola, S. \& Hauser, C. (2018, January 19). One after another, athletes face Larry Nassar and recent sexual abuse. The New York Times. Retrieved from https:/www.nytimes.com/2018/01/19/sports/larry-nassar-women.html?module=inline

[9] Johnson, R. (2017, June 27). USA Gymnastics releases Deborah Daniels' report, aims for cultural shift. FloGymnastics. Retrieved from https://www.flogymnastics.com/articles/5067323-usa-gymnastics-releases-deborah-daniels-report-aimsfor-cultural-shift

[10] Winchel, B. (2018, October 19). 3 lessons learned from USA Gymnastics' leadership struggle. Ragan's PR Daily [Blog]. Retrieved from https://www.prdaily.com/3-crisis-lessons-from-usa-gymnastics-leadership-struggle/ 